Рад примљен: 18. 7. 2017.

Рад прихваћен: 3. 3. 2018.

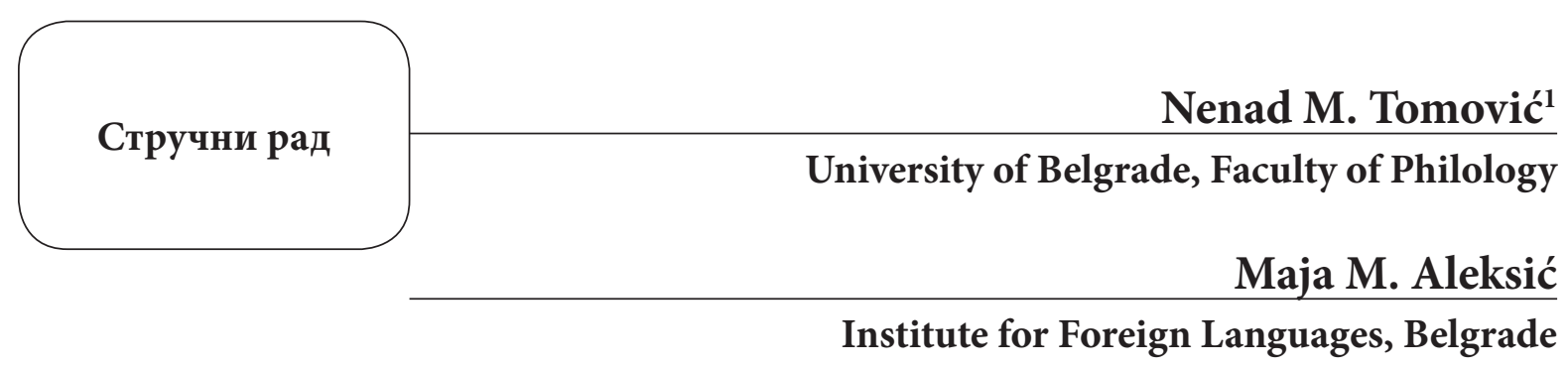

\title{
Expanding and outer circle cultural content in english coursebooks commonly used in Serbia
}

\begin{abstract}
The three core culture areas commonly covered by modern coursebooks are Inner Circle cultures (culture of countries where English is the first or dominant language), Outer Circle cultures (post-colonial countries where English plays a major role) and Expanding Circle cultures (other countries where it is spoken as a foreign language), as defined by Kachru (1985). The aim of this paper is to analyze how Expanding and Outer Circle cultural content is represented in English coursebooks commonly used in Serbia. The coursebooks used for this analysis were published by eminent British publishers and are widely available throughout Europe and on other continents. In order to establish cultural elements found in these coursebooks, the authors examined texts, tapescripts and other activities and tasks utilizing the Expanding and Outer Circle cultures. The authors opted for cultural elements that could be easily identified as such and used in a minimal context which can be clearly associated with a particular culture. The authors conclude that all coursebooks represent other cultures from an Inner Circle viewpoint, while the representation of other cultures ranges from their absence to equality, although the Expanding Circle cultures are typically restricted to those found in the Western world.
\end{abstract}

Keywords: Inner Circle, Outer Circle, Expanding Circle, cultural content, English coursebooks.

\section{Introduction}

Although languages are usually associated with the culture they convey, the situation with English is somewhat different. Being a global language, it is a means of communication both in the countries where it is spoken as the first or second language, and among non-native speakers. Thus, many varieties of English, which are no longer confined by national borders, are found in everyday use throughout the world. On the other hand,

1 nenad.tomovic@fil.bg.ac.rs

Copyright $\odot 2018$ by the authors, licensee Teacher Education Faculty University of Belgrade, SERBIA.

This is an open access article distributed under the terms of the Creative Commons Attribution License (CC BY 4.0) (https://creativecommons.org/licenses/by/4.0/), which permits unrestricted use, distribution, and reproduction in any medium, provided the original paper is accurately cited. 
English coursebooks are always based on some sort of culture, and a coursebook without cultural elements is virtually unheard of. Furthermore, cultural content in coursebooks can vary, especially when it comes to cultures of countries where English is taught as a foreign language.

Therefore, as a language of global communication, English has a multiple role - to introduce the culture of the countries where it is primarily spoken, but also to serve as a means of introducing other cultures and of bringing world cultures closer. In practical terms, presentation of other cultures can be beneficial for the learner for various reasons, and we will state just some of them: the learner can get to know cultures he/she is likely to (have) come into contact with, or if it is the learner's culture, he/she will identify with the content of the activity, which might provide some extra motivation; the fact that the world has become a global community is just another reason for incorporating other cultures, because intercultural competence, i.e. "the ability to communicate effectively in crosscultural situations and to relate appropriately in a variety of cultural contexts" (Bennett and Bennett, 2004:119), has virtually become a necessity in the modern world.

\section{Concepts and definitions}

To begin with, let us establish the meanings of certain concepts. The most important one is culture, and it can be defined in many ways due to its elusive nature. Byram and Grundy state that in language teaching culture has a very pragmatic definition - it is simply " $\mathrm{a} /$ the culture associated with a language being learnt" (Byram and Grundy 2003:1). For the purpose of this paper, their definition is too broad, and we will thus use a simple dictionary entry from American Heritage Dictionary and say that culture comprises all arts, beliefs, customs, institutions, and other products of human work and thought considered as a unit, especially with regard to a particular time or social group ${ }^{2}$. On the other hand, there are authors who perceive that culture also involves language, most notably Kramsch (1998:10), who defines culture as "membership in a discourse community that shares a common social space and history, and common imaginings." Furthermore, as Brown noted, culture is an integral part of the interaction between language and thought, while cultural patterns of cognition are coded in language (Brown, 2004: 188). Just like Kramsch, this author also emphasizes the link between discourse and culture by stating that conversational discourse styles can also be a cultural factor.

Although language and culture cannot be easily separated, it is important to note that English is not only the exponent of culture(s) of the countries where it is spoken as the first language, because it belongs to a much wider community. To further elaborate this, we will use the Three Circles model proposed by Kachru (1985). According to this author, the Inner Circle comprises the countries where English is traditionally spoken, which provide the norms, and the varieties spoken that are considered to be native speaker varieties, e.g. those spoken in the UK, USA, Australia, Canada, etc. The Outer Circle includes the countries where English serves as a lingua franca, where it is used in public communication and/or for official, educational and other purposes, e.g. India, Kenya, etc. Finally, all other countries where English is spoken as a foreign language, where it is not used for official purposes, but is used in international communication belong to the Expanding Circle.

\section{Learner needs and cultural elements}

According to internal surveys carried out by the Institute for Foreign Languages, there is a majority of students (about $70 \%$ in the last five

\footnotetext{
2 American Heritage ${ }^{\oplus}$ Dictionary of the English Language, Fifth Edition. (2011). Retrieved January 28, 2017 from http://www. thefreedictionary.com/culture
} 
years) who are extrinsically motivated ${ }^{3}$; they need English for their everyday business activities and contacts with foreigners, both native and non-native speakers, and thus need not only to acquire vocabulary as such, but also to master the norms of communication, speech acts, appropriacy and elements of discourse so as to make communication successful. Approximately 20\%-25\% of students are intrinsically motivated; the rest need English for other purposes. In that regard, the activities we analyzed often provide the learner with conversational norms and expected reactions, at least in the case of Inner Circle cultures. For example, a person from the Mediterranean, Serbia included, might find useful a text about kissing (Why Britain suffers a kissing crisis? in Language to $G o$ ), because the concepts of personal space, physical contact and kissing as a sign of affection between friends might differ. English coursebooks available on the Serbian market are usually those published by CUP, OUP, Pearson Longman or Macmillan. Being written in the UK, they are aimed for international students who learn English in their home countries or in the UK, while all of them are based on an Inner Circle worldview, which means that the culture they are based on is Anglo-American. These books are focused on integration and/or international communication, although some of them are virtually devoid of cultural elements that belong to the Outer and External Circle unless they are more or less known in English-speaking countries.

3 We will use the definitions given by Harmer to explain extrinsic and intrinsic motivation. According to Harmer (2007:98), extrinsic motivation "is the result of [...] of outside factors, for example the need to pass an exam, the hope of financial reward or the possibility of future travel. Intrinsic motivation [...] comes from within the individual. Thus, a person might be motivated by the enjoyment of the learning process or by a desire to make themselves feel better." In other words, extrinsic motivation means that the learner learns something because he/she needs it, while intrinsic motivation comes down to liking the subject one learns.

\section{Methodology}

In order to establish cultural elements found in the coursebooks we decided to analyze, we examined texts, tapescripts and other activities and tasks which utilize cultural elements. We opted for cultural elements which could be easily identified as such and used in a minimal context which can be easily associated with a particular culture, where both the culture and its elements are easily identifiable, e.g. Paella is a famous Spanish dish. Of course, a particular culture and its elements do not have to be mentioned in the same sentence, while any kind of minimal context that allowed us to identify the culture was sufficient to include the element in the analysis. In other words, cultural elements had to be mentioned explicitly as such or within the cultural context they belong to. On the other hand, scattered elements which originate from Expanding Circle cultures (e.g. pizza, French fries and the like in non-Italian/non-French contexts) were not taken into account, because they are now most commonly part of every major culture and are not usually felt as 'foreign' elements.

For the purpose of this research the coursebooks we analyzed are divided into three categories according to the degree of presence of Expanding/Outer Circle cultural elements.

1 zero or minimum degree presence

2 medium degree presence

3 high degree presence

Zero or minimum degree presence refers to low incidence of any cultural elements that can be easily associated with Expanding/Outer Circle cultures or to a complete lack of these elements. However, if any non-Inner Circle elements occur, this is only sporadic and the elements in question do not convey any cultural information which a student might utilize in order to learn about a particular culture. The coursebooks that fall under 
this category are the following : Language to Go, Complete Advanced, Face 2 Face, Objective First, FCE Result, Ready for FCE and Advance Your English.

Medium degree presence refers to the following cases: cultural elements do not appear regularly, they do not always have a clear educational purpose, i.e. they are not necessarily intended to teach the student about a different culture and are most commonly used as sources of primarily/ solely linguistic information. Finally, they do not appear in each lesson and are more or less scattered throughout the coursebook. The coursebooks that fall under this category are: Complete Advanced and Framework 4.

High degree presence refers to frequent and/ or regular use of cultural elements (e.g. in every second lesson) associated with Expanding/Outer Circle cultures which can both serve as sources of information or knowledge about other cultures and also provide linguistic material for $\mathrm{L} 2$ learning. The coursebooks that fall under this category are English Unlimited and New Framework 5. In fact, it is important to state that English Unlimited is the most prominent example of a coursebook that promotes culture, because it even contains sections devoted to culture which appear at regular intervals, i.e. after each second unit.

If we look at the categories these coursebooks belong to, it is quite obvious that most of them contain few or no elements of cultures other than those that belong to the Inner Circle. This seems to be a small paradox: although the books are intended for international students, there are actually many texts which describe e.g. a British ex-pat or a tourist instead of a foreigner learning English, who is the primary user of each book. Although L2 learners need this kind of perspective, it would be useful to include a foreign perspective so as to make the coursebooks more versatile. It is possible that some authors/publishers decided to write

4 Full bibliographic information about the coursebooks can be found in the References section. "sterile" coursebooks to make them more easily saleable and/or to facilitate integration into a new environment and possibly assimilation. A drawback of this approach can be that some students are not sufficiently familiar with the target culture.

Activities in which cultural elements occur are standard coursebook activities, i.e. those which focus on L2 development. As such, they can have a multiple purpose. For example, a listening activity can serve to improve students' listening skill, but also to raise awareness about certain cultures, or to provoke students to state their views about another culture. We should also add that although authors do not impose their views, it is evident that coursebooks which belong to the second and third category actively promote multiculturalism as one of the esteemed values of modern society. Of course, coursebooks which belong to the first category are not aimed against other cultures, but are simply focused on the Inner Circle and common Western heritage. Besides, the coursebooks with this focus can also be useful to inform students who wish to integrate into the Inner Circle societies about their respective cultures.

\section{Analysis and discussion}

After analyzing the coursebooks, we decided to list their common features first. All of them can be described as West-centered, i.e. they are written from a Western point of view and seem to cater to the needs of a student whose cultural heritage is primarily European. Furthermore, the point of view can be narrowed down to a more or less British perspective. On the other hand, it does not mean that non-English audience is excluded - all authors tend to make the content as "international" as possible so as to make the books accessible to a wider audience, regardless of their origin or cultural background. The books can thus be used in many countries, which makes them likely to be globally accepted. It is also worth noting that there 
is always awareness of the Other, namely that not all characters are typically British (American, Australian, etc.) and/or of that heritage. Many of them have non-English names, while there are also foreign characters, and most of them are there to learn English. None of the books requires profound knowledge of any particular culture, although many of them are characterized by a Western point of view. For example, all landmarks and places are described in the form of a tourist brochure or very similar to it, as if intended for educational or travel purposes, which may correspond to their practical purpose. The appropriacy of materials can sometimes vary in relation to students' cultural backgrounds, which means that an activity that features culture can be a barrier. For example, a student from China may find it difficult or impossible to discuss Elvis Presley, Humphrey Bogart, rugby or baseball if they are not popular in his/her country, i.e. if the activity requires some previous knowledge about the person/concept in question. Of course, this problem is usually solved by providing some background information about them.

Regardless of the characters' linguistic and/ or cultural background, the discourse used in all coursebooks belongs to the Inner Circle. Although this convention is strictly followed in all coursebooks, and not only in the ones that we analyzed, it is worth mentioning that there is not a single learner of an L2 who does not make mistakes at this level. However, this convention is justified, because students are supposed to be provided with authentic linguistic material. Addressing other people is usually devoid of exaggerated formality, which means that titles like $M r, M r s$, Miss or Ms. are used sparingly and thus illustrate how low power-distance cultures deal with this problem. A learner from another country will find it useful to learn that it is perfectly acceptable to address a superior by using his/her first name instead of $M r, M r s$, Miss or Ms. + FAMily NAME. Communicative acts between members of all circles sound as if happening between members of the Inner Circle, which means that all conventions are strictly followed, and the characters function as if they were pure British (American, Canadian, Australian, etc.). Materials do not contain sociopragmatic or pragmalinguistic failures, although we might say that this seems a bit far-fetched. Again, we cannot criticize the authors, because their aim is to teach the learner how to function properly.

Cultural taboos are generally avoided. Authors tend not to include things that are taboos in the West, such as eating dog meat, but they also avoid some taboos from other cultures, e.g. eating beef (a taboo in India), etc. Of course, there are a few minor exceptions, such as asking students to write their own obituary or to discuss photos, among which there is one of a gay couple, which is taboo in some parts of the world.

However, since there are no coursebooks that are completely devoid of cultural differences, all of those analyzed introduce them in one way or another.

For example, gestures and body language have different meanings in different cultures, e.g. rubbing noses, shaking hands, bowing, the $\mathrm{OK}$ sign, etc. In some cases, they can even be associated with behavior patterns, i.e. good or bad manners, because social conventions can vary. For example, in some cultures it is acceptable to put your feet on the desk or to take off your shoes in the office, while in some others these things are frowned upon. Framework 4, New Framework 5 and Language to Go provide information about how we use gestures in the cultures that belong to the Inner Circle. These examples show that teaching culture is present in coursebooks that belong to all three categories and that it cannot be separated from learning an L2.

Regardless of the categories each coursebook belongs to, there is a general tendency to exploit culture in such a way as to provide a background for introducing or checking linguistic elements which are in focus, e.g. a text which includes cultural elements can be a cloze test (e.g. a text about pyramids in Objective First), a multiple choice vocabulary 
exercise (e.g. a text about Bollywood in Complete Advanced), they can focus on verb forms (e.g. a text about a Spanish artist in English Unlimited), word formation, relative pronouns etc. Culture is thus dominantly used as a means to a primarily linguistic end. This tendency is understandable, since the main purpose of a language coursebook is to provide linguistic contents and information.

On the other hand, some authors opted for a different approach, i.e. they decided to teach both language and culture. English Unlimited and New Framework 5 feature all three circles rather equally and are examples of coursebooks which teach culture. Although they are not the only coursebooks that teach culture, they certainly promote cultural diversity.

After analyzing the coursebooks, we can state that the Inner Circle and its cultures dominate all coursebooks and comprise about $70 \%$ of all cultural materials. It is the case with all three categories, while the percentage given here is the average. The books that teach culture usually teach Inner Circle cultures and thus feature corresponding movies, music, actors, singers, arts, and the like, or describe some even more specialized events or phenomena, for example, what butlers do today (Advance Your English). Literary texts which are sometimes used are also those written by English-speaking authors and usually deal with British or American topics.

Outer Circle cultures do not appear very frequently. This circle is represented by around $10 \%$ of all cultural materials. A possible explanation for this low frequency might be the fact that Outer Circle cultures are better known to an average member of the Inner Circle than to a common Westerner from a non-English speaking country. Of course, notable exceptions such as the ones we have just mentioned, are present. Some of the examples we have found include Nelson Mandela, Soweto, Bollywood, the Nigerian writer Chinua Achebe, etc. Overall, India and its culture are most common among these examples, which is understandable, because this huge country and its civilization are known world-wide, while many people from India live in the countries that belong to the Inner Circle and many other countries.

As we can expect, Expanding Circle cultures appear in all coursebooks and are used in ways which have already been mentioned, namely as a means to achieve language proficiency and to provide language practice. Their percentage varies from one book to another, although the average is about $20 \%$. Overall, about $70 \%$ of Expanding Circle cultures are European and belong to common European heritage, such as Greek philosophy, Renaissance art, European classical music, fairytales, etc. Examples from Expanding Circle cultures usually involve events, people, arts, phenomena, which are assumed to be familiar to most Westerners, thus ensuring that the coursebook can be used with a very wide range of potential students.

In case of the Expanding Circle, there are two coursebooks that provide multiple examples of materials which raise students' awareness of nonWestern cultures, like texts about Umm Khultum and Jang Nara, famous entertainers from Egypt and Korea respectively (English Unlimited) or texts which describe gang culture in El Salvador, attitudes towards pets in Japan, etc. (New Framework 5). We can also add that these two coursebooks provide a good balance between Western and non-Western cultures.

\section{Conclusion}

If we look at all coursebooks included in the analysis, it is possible to list their common features in terms of the three cultural circles. To begin with, regardless of the category they belong to, it is evident that the point of view is Western, and almost always British, because the prevailing standpoint is that a European/British writer presents his/her own culture and cultures he/she is familiar with to an outsider. Although it is certain that all authors 
have a positive attitude towards multiculturalism and that they present other cultures positively, the coursebooks do not make it very obvious that English now belongs to many nations and cultures, or that it is a lingua franca, which separates it from the culture it stems from.

Therefore, the Outer and Expanding Circle cultures are less present than Inner Circle cultures in all coursebooks. In most of them, these are found sporadically, and usually to be used just for teaching language. The coursebooks which educate on culture are in minority.

In modern times when multiculturalism and integration are in focus one might expect the Outer and Expanding Circles to be more present and that there should be some kind of balance between the Western and non-Western perspectives.

On the other hand, it should be taken into account that many Inner Circle countries have immigrants from all over the world and there is a strong need for their integration. Furthermore, there are also teachers who think that teaching Inner Circle cultures is as important as teaching the language and these teachers are often inclined to select the coursebooks which provide extensive information about these cultures. We should also take into account that many learners of English actually like the Inner Circle and its cultures and are eager to learn about them.

If it is necessary to choose between a coursebook which focuses solely on the Inner Circle, one which includes the other two circles, or even a coursebook targeted for a specific market and written specifically for speakers of, say, Spanish, Chinese, or any other language, we must take into account several factors - learners' needs, their motivation, as well as their educational and linguistic background. Although it is impossible to provide a definite answer, we can say that the coursebooks that focus on the Inner Circle are at least a safe choice if most of the students plan to function in an Inner Circle environment or wish to integrate. Books which include the other two circles can sometimes pose a problem for students who do not come from Western countries and cultures, since they might need additional explanations if certain cultural phenomena are unknown to them. It would be ideal if a teacher could find a book which provides a good balance between different cultures and enough cultural information which facilitate life in the globalized and multicultural world of today.

\section{References}

- Bennett, J. and M. Bennett (2004). Developing intercultural sensitivity: An integrative approach to global and domestic diversity. In D. Landis, J. Bennett and M. Bennett (eds.), Handbook of Intercultural Training (3rd ed.) (pp. 145-167). Thousand Oaks: SAGE.

- Broadhead, A. (2003). Advance Your English. Cambridge: Cambridge University Press.

- Brook-Hart, G. and S. Haines. (2015). Complete Advanced. Cambridge: Cambridge University Press.

- Brown, H.D. (2000). Principles of Language Learning and Teaching. London: Longman.

- Byram, M. and P. Grundy (eds.) (2003). Context and Culture in Language Teaching and Learning. Clevedon: Multilingual Matters LTD.

- Capel, A. and W. Sharp. (2015). Objective First. Cambridge: Cambridge University Press.

- Clare, A. and J.J. Wilson. (2013). Language to Go. Harlow: Pearson

- Tilbury, A. et al. (2014). English Unlimited. Cambridge: Cambridge University Press. 
- Davis, P and T. Falla. (2008). FCE Result. Oxford: Oxford University Press.

- Goldstein, B et al. (2009.) New Framework 5 Advanced. Oxford: Richmond.

- Harmer, J. (2007). The Practice of English Language Teaching. Harlow: Pearson.

- Jeffery, P., M. Lloyd and B. Goldstein. (2009). Framework 4, Upper-Intermediate 4, Richmond Publishing.

- Kachru, B.B. (1985). Standards, codification and sociolinguistic realism: the English language in the Outer Circle. In R. Quirk and H.G. Widdowson (eds.), English in the world: Teaching and learning the language and literatures (pp. 11-30). Cambridge: Cambridge University Press.

- Kramsch, C. (1998).Language and Culture. Oxford. Oxford University Press.

- Norris, R. (2008). Ready for FCE, London: Macmillan.

- Redston, C. and G. Cunningham. (2014).Face 2 Face. Cambridge University Press. 


\author{
Ненад М. Томовић

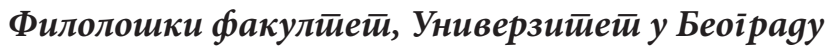 \\ Маја М. Алексић \\ Инсииитиуй за сииране језике, Беоіраg
}

\title{
САДРЖАЈИ КУЛТУРА ШИРЕГ И СПОЉАШЊЕГ КРУГА У УЏБЕНИЦИМА ЕНГЛЕСКОГ ЈЕЗИКА КОЈИ СЕ КОРИСТЕ У СРБИЈИ
}

У тири кључне кулитуре које се најчешће обрађују у савременим уибеницима сйаgају

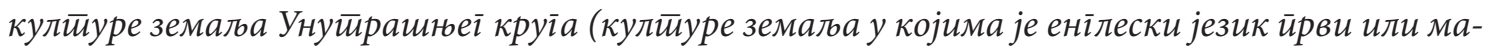
иеерюи језик), Ширеі круїа (кулииуре йосииколонијалних земаља у којима је енїлески gруіи је-

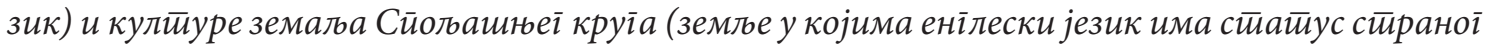
језика). Циь иситраживань ойисаноі у овом раgу био је gа се уйврgи како су саgржаји йове-

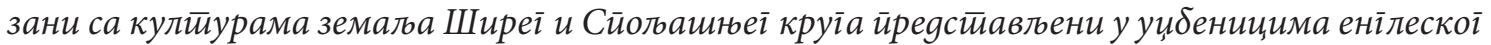
језика који се најчешће користе у Србији. Овим раяом су обухваћени уибеници еминенитних изgавачких кућа: Cambridge University Press, Oxford University Press, Pearson u Macmillan uз Be-

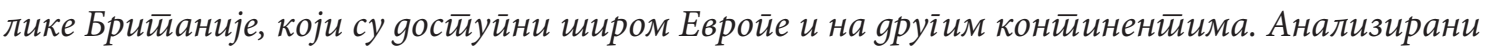

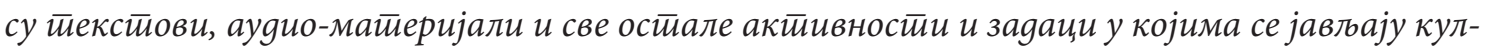

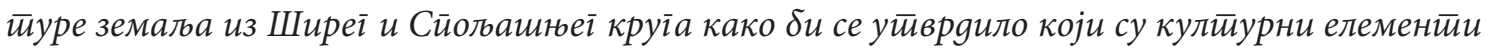

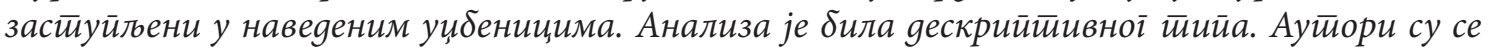

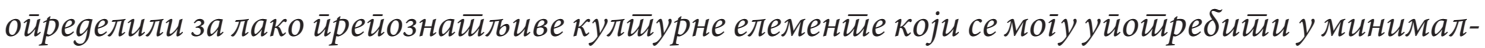

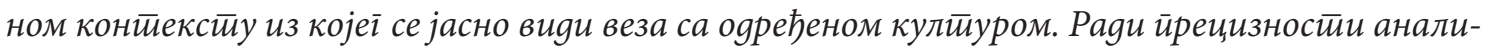

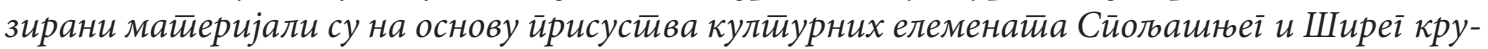
іа йоgетьени у йри кайеі̄орије: они који имају 1) нулито или минимално йрисустиво наведених

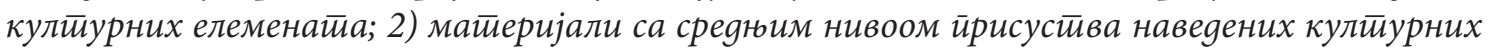

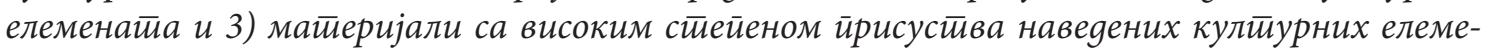
нат̄а. У йрву кайеі̄орију сйаgају уибеници Language to Go, Complete Advanced, Face 2 Face, Objective First, FCE Result, Ready for FCE u Advance Your English, y gpyīy Complete Advanced

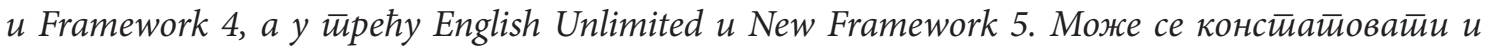

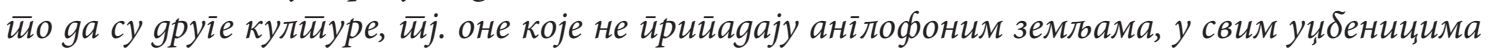

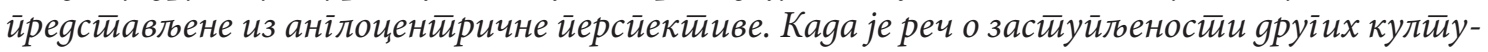

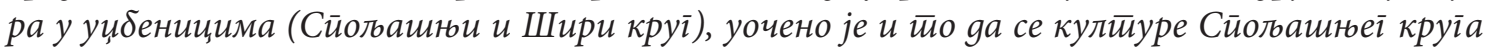
уіллавном своgе на кулииуре зайаgних земаль, йа се као још јеgна зајеgничка каракииерисиии-

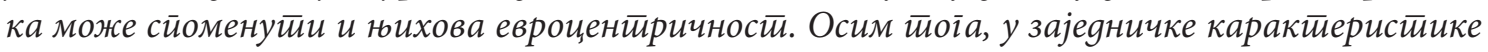

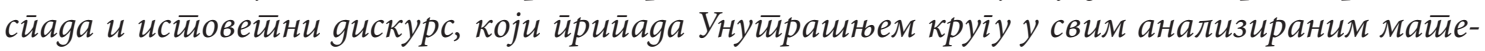

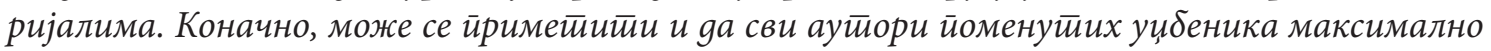

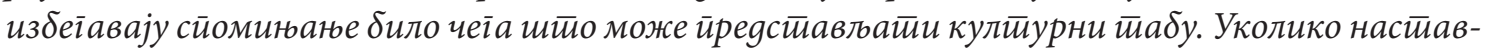

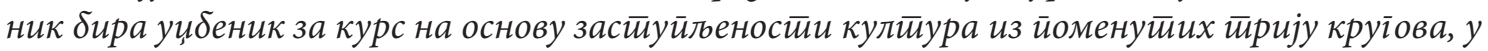

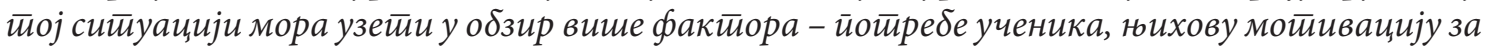


учене ені̄лескої, ирреихходно образоване и језик/језике које ученик зна. Уибеници фокусирани на Унуйрашти круі су најбоља ойција уколико већина ученика намерава gа се иниееірише у куліиуре Унутирашюеі круїа и gа функиионишу у ғиховом оквиру. Уибеници бокусирани на остиала gва круїа моїу битии неаяекваитни за ученике који не живе у землама Зайаgа или не

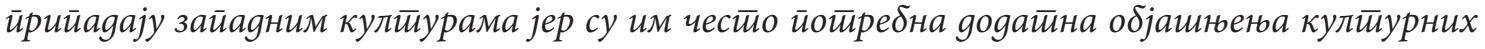

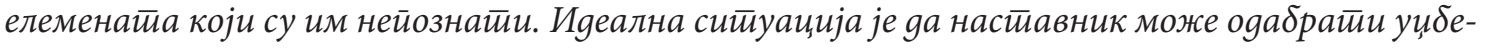
ник у коме су равномерно застиуйлене кулитуре из свих йрију итоменуйих круіова, уз довољно информација о кулитурама које су ученицима gалеке, шимо може олакшаиии функционисате

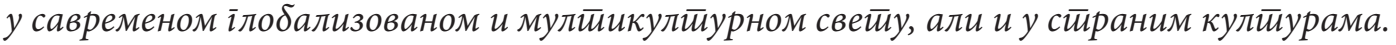

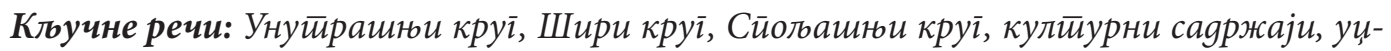
беници енїлескоі̄ језика. 